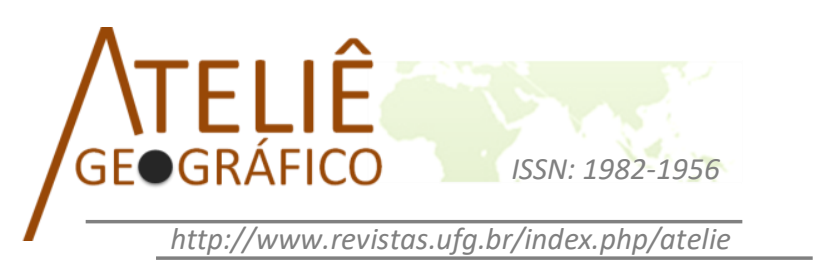

\title{
A produção imobiliária, a propriedade da terra, o trabalho e o espaço urbano: o caso da Região Metropolitana da Grande Vitória - ES - Brasil
}

\section{La producción de vivienda, la propiedad de la tierra, el trabajo y espacio urbano: el caso de la Región Metropolitana de la Grande Vitória - ES - Brasil}

La production immobiliere, la propriété foncière, au travail et l'espace urbain: le cas de la Région Métropolitaine de la Grande Vitória - ES Brésil

Francismar Cunha Ferreira

Universidade Federal do Espírito Santo

francismar.cunha@gmail.com

Cláudio Luiz Zanotelli

Universidade Federal do Espírito Santo

clzanotelli@yahoo.com.br

\begin{abstract}
Resumo
$\mathrm{O}$ artigo analisa as relações entre a propriedade da terra, o trabalho e a produção imobiliária na Região Metropolitana de Vitória no estado do Espírito Santo. Estudamos 13 empreendimentos com diferentes tipologias e localizações voltados para diferentes segmentos econômicos. Nestes, estudamos as relações entre os promotores imobiliários, os proprietários de terra e a força de trabalho a partir de análises sobre taxa de mais valia, taxa de lucro, taxa renda da terra e os rebatimentos destes processos no espaço urbano. Percebemos que as taxas de lucro, mais-valia e da renda da terra são sensíveis às diferenças de tipologias, ao tamanho, à localização, ao preço do terreno, ao número de unidades, ao tamanho da área construída, ao preço de venda dos empreendimentos e à exploração do trabalho. O lucro do promotor imobiliário ora tem maior parte advinda da taxa de renda da terra, ora da exploração do trabalho. Entretanto, existem casos onde a taxa de renda da terra e de mais-valia são elevadas, proporcionando enormes taxas de lucro aos promotores imobiliários.
\end{abstract}

Palavras chaves: espaço urbano; produção imobiliária; renda da terra. 


\begin{abstract}
Resumen
El artículo analiza relaciones entre propiedad de la tierra, trabajo y producción de vivienda, en la Región de Vitória en el estado de Espirito Santo. Estudiamos 13 proyectos de diferentes tipos y ubicaciones. Se analiza las relaciones entre promotores inmobiliarios, propietarios de tierras y mano de obra a partir de análisis sobre la tasa de plusvalía, tasa de ganancia, tasa de renta de la tierra y las repercusiones de estos procesos en el espacio urbano. Percibimos que las tasas de ganancia, plusvalía y de renta de la tierra son sensibles a las diferencias en los tipos, el tamaño, la ubicación, el precio de la tierra, el número de unidades, el tamaño de la superficie construida, el precio de venta y la exploración del trabajo. Las ganancias del promotor inmobiliario ahora poseen mayor cantidad proveniente de la tasa de renta de la tierra, ahora de la explotación del trabajo. Sin embargo, existen casos, donde las dos tasas son elevadas, favoreciendo la tasa de ganancia del promotor inmobiliario.
\end{abstract}

Palabras clave: espacio urbano; la producción de vivienda; renta de la tierra.

\title{
Résumé
}

L'article analyse les rapports entre le secteur immobilier, la propriété foncière et le travail dans la région de Vitória, état d'Espírito Santo au Brésil. Nous avons étudié 13 différents ensembles de logements avec des typologies et localisations différenciées. On été analysés les rapports entre les agents immobiliers, les propriétaires fonciers et la force de travail a partir des taux de plus-value, de profit et la rente de la terre et leurs répercussions dans l'espace urbain. Les gains sont variables selon les différences dans les types, la taille, l'emplacement, le prix de la terre et le nombre d'unités construites. Les profits provienent autant des rapports salariaux que de la rente extraite de la terre. Cependant, il $\mathrm{y}$ a des cas où même quand il y a des différences entre le taux de la rente de la terre et les taux de plus value, les deux sont elevés, ceci amène a un profit très important pour les agents immobiliers.

Mots-clés: l'espace urbain; la production de logements; rente foncière.

\section{Introdução}

A RMGV está localizada no estado do Espírito Santo - Brasil (cf. figura 01). É formada oficialmente por 7 municípios ${ }^{1}$. Possui uma área total de aproximadamente $2.311 \mathrm{~km}^{2}$. Destes, $1464,97 \mathrm{~km}^{2}$ correspondem ao perímetro rural e $846,45 \mathrm{~km}^{2}$ são apontados como áreas de perímetro urbano. Entretanto, nem todo o perímetro urbano é utilizado por atividades urbanas. Há dentro do perímetro urbano áreas que são ocupadas por usos agropastoris, principalmente nas franjas urbanas e também uma área urbana densa onde se verifica uma maior densidade de edificações e equipamentos urbanos. Essa área urbana densa na RMGV ocupa aproximadamente $327 \mathrm{~km}^{2}$ do perímetro urbano, ou seja, apenas $38,64 \%$ do espaço apontado como urbano possui uma ocupação relativamente densa, afinal, dentro desta mancha urbana dita densa existem também áreas sem edificações. Os outros $61,36 \%$ da área definida como

\footnotetext{
${ }^{1}$ Lei complementar N. ${ }^{\circ}$ 204, de 22 de junho de 2001 estabelece a RMGV formada pelos municípios de Cariacica, Fundão, Guarapari, Serra, Viana, Vila Velha e Vitória. A área urbana conurbada da RMGV é formada por apenas 4 municípios (Cariacica, Serra, Vila Velha e Vitória).
} 
urbana pelo perímetro urbano de acordo com Zanotelli et. al. (2014) podem ser compreendidos como sendo os chamados "vazios urbanos" 2 .

Em relação aos seus aspectos populacionais, de acordo com o Instituto Brasileiro de Geografia e Estatística (IBGE, 2010), a RMGV possui uma população de 1.687.704 habitantes, o que representa 48\% da população do estado do Espírito Santo. Sua densidade demográfica é de aproximadamente 730 habitantes por quilômetro quadrado. Na figura 01 podem ser visualizadas essas informações.

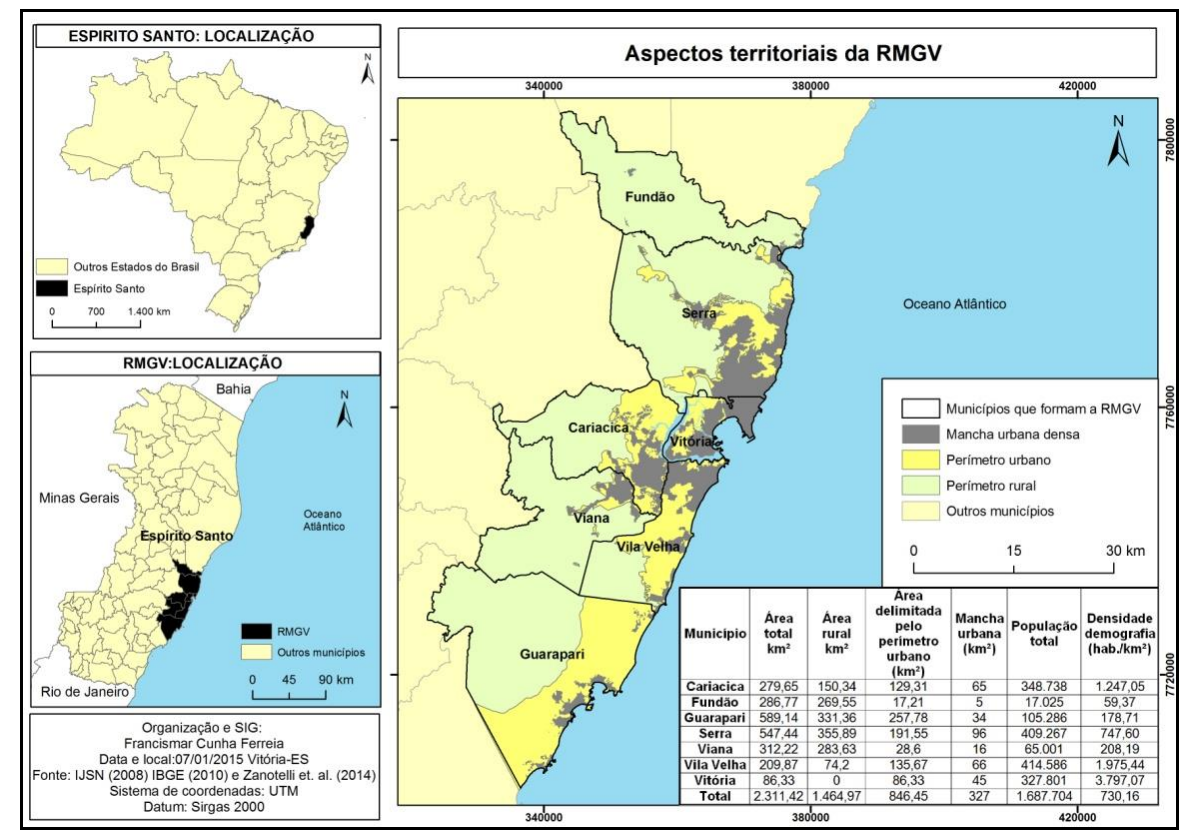

Figura 01: Localização e aspectos gerais da RMGV.

Quanto à produção imobiliária na RMGV, ela se consolidou por volta da década de 1970 inicialmente na capital Vitória. Na década de 1990, o município de Vila Velha se insere nesse processo. A partir dos anos 2000 o município de Serra também passa a receber investimentos imobiliários. Ultimamente, verifica-se uma significativa participação do município de Cariacica como área da expansão da produção imobiliária e mais recentemente, ainda de maneira tímida, o município de Viana, também vem sendo local de lançamentos imobiliários.

\footnotetext{
${ }^{2}$ A área total de vazios urbanos da RMGV ainda é maior, uma vez que no interior da mancha urbana densa existem significativos vazios urbanos que são identificados apenas em grandes escalas de análises. Para maiores informações sobre os vazios urbanos, em especial os da RMGV, ver Zanotelli et. al. (2014).
} 
A expansão e a dispersão da produção imobiliária na RMGV podem ser compreendida, de maneira geral, pela busca por terras para a construção, sendo que a terra necessita ser adquirida a cada novo empreendimento, uma vez que ela não é produzida pelo trabalho, e é monopolizada por lei de propriedade, o que faz com que seu dono exija uma renda - cobre um preço - para que outros tenham acesso a ela. Logo o preço da terra (a renda da terra) e a necessidade da mesma para a construção, definem, em partes, o deslocamento da produção imobiliária pelo território. Além disso, soma-se inicialmente a esse processo a chegada de empresas capitalizadas em bolsas de valores externas ao Espírito Santo que passaram a produzir imóveis em novos bairros na RMGV, motivando assim uma expansão e uma dispersão da produção imobiliária pelo espaço urbano. Outro elemento que contribuiu para o aumento e a dispersão da produção imobiliária da RMGV foi a partir de 2009 a implantação do Programa Minha Casa Minha Vida (PMCMV). Um programa destinado à construção de moradias para a população que possui rendimento de até 10 salários mínimos e que foi elaborado em parceria entre Governo Federal e empresas da construção civil financerizadas (TONE, 2010) ${ }^{3}$. Essas empresas em seus empreendimentos voltados para as classes de menor renda buscam, dentre outras coisas, terrenos mais baratos para produzir para um público de menor renda sem perder seus lucros. Como consequência, desta busca por terras mais baratas, as empresas acabam lançando empreendimentos em bairros periféricos da metrópole. Como implicação disto, tem-se um espraiamento da produção imobiliária e uma valorização imobiliária e fundiária em regiões centrais e periferias.

A produção imobiliária que se desenvolve na RMGV desde a década de 1970 teve caráter empresarial. É uma produção imobiliária voltada para o mercado que, de modo geral, tem em vista a possibilidade de valorização de capital por meio da construção (CAMPOS JR. 2002). Essa busca de valorização do capital via a produção imobiliária motiva o surgimento de diversas estratégias desenvolvidas por promotores imobiliários em torno do produto imobiliário, da propriedade da terra e do trabalho. $\mathrm{O}$ desenvolvimento destas estratégias e da busca de lucros imobiliários associados à terra e a exploração do trabalho, acaba motivando diversos impactos na organização do espaço urbano e consequentemente na vida urbana. Entretanto cabe perguntar como o promotor imobiliário consegue valorizar seus capitais via produção imobiliária de mercado? Como a propriedade da terra entra no processo de valorização imobiliária? Com o trabalho se relaciona com a produção imobiliária neste processo?

\footnotetext{
${ }^{3}$ O PMCMV tem várias formas de subvenção em função do rendimento familiar. Os recursos utilizados são oriundos de fundos compulsórios geridos pelo estado brasileiro e da contribuição compulsória sobre o salário de cada trabalhador (Fundo de Garantia por Tempo de Serviço (FGTS)) e do orçamento do estado brasileiro. É o maior programa de habitação no Brasil nos últimos 30 anos. Estão previstas no total, 3,4 milhões de moradias (com possibilidade de ampliação para o período de 2015 - 2018). Em 2014, 1,5 milhões de moradias haviam sido construídas e cerca de 205 bilhões de reais investidos (RONCHI, 2014).
} 
Tendo em vista estas questões o presente artigo tem como objetivo estudar o processo da construção analisando as relações entre os promotores imobiliários, os proprietários de terra e a força de trabalho no processo da construção a partir de algumas análises sobre a taxa de mais valia, taxa de lucro, taxa renda da terra e os rebatimentos deste processo no espaço urbano, em especifico, na RMGV.

Cabe destacar desde já que os pressupostos aqui trabalhados podem possuir algumas limitações uma vez que é extremamente difícil identificar algumas questões como taxa média de lucro, equalização da taxa de lucro e etc.. Realizamos um exercício que vem sendo desenvolvido pela pesquisa "A expansão da Região Metropolitana da Grande Vitória: a terra é o nó" coordenado pelo professor Cláudio Zanotelli, que busca colocar em discussão a renda fundiária urbana e suas relações com a produção do espaço urbano e finalmente contribuir para a compreensão estrutural do ambiente construído em um momento da história onde a urbanização é central para a absorção e valorização de capitais (HARVEY, 2014) e onde o imobiliário em geral (com a construção) deixa de se apresentar com um circuito secundário um setor anexo e que foi durante muito tempo considerado atrasado em relação ao capitalismo industrial e financeiro, para passar ao primeiro plano (LEFEBVRE, 2000).

Inicialmente, elencamos 13 empreendimentos de diferentes tipologias (verticais e horizontais) voltados para grupos sociais distintos (parte inseridos no Programa Minha Casa Minha Vida (PMCMV) e outra parte voltado para um público de maior poder aquisitivo), para realizarmos um estudo de caso sobre o processo da construção. A escolha de 13 empreendimentos específicos se deu em função do nosso objetivo de compreender o processo de construção em empreendimentos de diferentes tipos e voltados para diferentes segmentos econômicos. Além disso, essa escolha se justifica por termos optado por analisar empreendimentos produzidos pelas mesmas empresas em diferentes municípios da RMGV. Foram estudados 4 empreendimentos em Serra, 2 em Vitória, 3 em Vila Velha, 2 em Cariacica, 1 em Guarapari e 1 em Viana (cf. quadro 01 e figura 02).

Dos 13 empreendimentos analisados, obtivemos informações inerentes ao número, ao valor e ao preço médio do metro quadrado das unidades habitacionais, da área construída e área do terreno dos empreendimentos. Além disso, para sabermos informações inerentes ao preço médio dos terrenos dos empreendimentos, levantamos informações de preços de terrenos que se localizam nas proximidades dos mesmos. Ao todo, calculamos o preço e a área de 78 terrenos localizados próximos aos empreendimentos analisados.

Realizamos levantamos de informações inerentes ao custo da construção, que é medido por vários índices, mas, optamos no presente trabalho por utilizar os dados apresentadas nos relatórios mensais do Custo Unitário Básico da Construção (CUB) publicado pelo SINDUSCON-ES, pois esse indicador detalha os custos por metro 
quadrado concernente à força de trabalho, aos materiais de construção, equipamentos e despesas administrativas.

Para obter os preços de venda, área construída e do terreno e outras informações sobre os 13 empreendimentos analisados, realizamos 4 trabalhos de campo, onde visitamos os stands de venda dos empreendimentos e das empresas e também realizamos entrevistas com corretores que comercializam unidades dos empreendimentos analisados.

\section{A produção imobiliária e a propriedade fundiária na Grande Vitória}

A produção imobiliária representa para o promotor imobiliário uma possibilidade de valorização de capital. Neste sentido diversas estratégias são desenvolvidas pelos promotores entorno do produto imobiliário. Partes destas estratégias incidem sobre a organização do trabalho na produção e também sobre a terra. Neste sentido, a fim de compreender essa valorização de capitais via produção imobiliária baseada na exploração do trabalho e na apropriação da renda da terra buscamos analisar o processo de construção de diferentes empreendimentos.

Para a realização das referidas análises, nos baseamos na metodologia de estudo adotada por Lefèvre (1982) para a cidade de São Paulo. A metodologia apontada pelo referido autor, consiste na realização do levantamento de várias informações como preços de venda, área construída, custos da construção, número de unidades e etc. de empreendimentos imobiliários e de preços de terrenos no entorno dos empreendimentos. O objetivo de sua pesquisa através desta metodologia consiste em apontar por meio de alguns cálculos com os dados colhidos, o papel do terreno no lucro dos promotores imobiliários (LEFÈVRE, 1982). Entretanto, o presente estudo faz algumas adaptações da proposta metodológica de Lefèvre (1982) para a realidade da RMGV, onde buscamos por meio do levantamento de informações inerentes a preços de venda de unidades habitacionais, preço de terrenos do entorno dos empreendimentos analisados, custos de construção, área construída e etc. apontar por meio de alguns cálculos, não somente o papel do terreno no lucro dos promotores imobiliários, mas também verificar, algumas estratégias de lucros por parte dos promotores imobiliários por meio da apropriação da terra enquanto mercadoria e da exploração do trabalho no processo de construção. No quadro 01 pode ser visualizado as características gerais de cada empreendimento e na figura 02 pode ser visualizada a localização e as tipologias dos 13 empreendimentos analisados. 
Quadro 01: Características gerais dos empreendimentos analisados.

\begin{tabular}{|c|c|c|c|c|c|c|c|}
\hline $\begin{array}{c}\text { Nome do } \\
\text { Empreendimento }\end{array}$ & $\begin{array}{c}\text { Empresa } \\
\text { incorporadoral } \\
\text { construtora }\end{array}$ & Tipologia & Estágio & $\begin{array}{c}\text { Inserido } \\
\text { no } \\
\text { PMCMV }\end{array}$ & $\begin{array}{c}\text { Número } \\
\text { de } \\
\text { unidades }\end{array}$ & Bairro & Municipio \\
\hline Aldeia Manguinhos & Morar & Horizontal & Construção & Não & 63 & Manguinhos & Serra \\
\hline Ecolife da Vila & Ecovila & Vertical & Lançamento & Sim & 60 & Ataíde & Vila Velha \\
\hline Ecolife Santa Inês & Ecovila & Vertical & Lançamento & Não & 34 & Santa Inês & Vila Velha \\
\hline Ecovillage & Ecovila & Horizontal & $\begin{array}{c}\text { Recém- } \\
\text { construido* }\end{array}$ & Sim & 26 & Porto Canoa & Serra \\
\hline $\begin{array}{c}\text { Morada das } \\
\text { Cássias }\end{array}$ & Ecovila & Vertical & Construção & Sim & 176 & Kubistchek & Guarapari \\
\hline $\begin{array}{c}\text { Parque das } \\
\text { Gastanheiras }\end{array}$ & Galwan & Vertical & Construção & Não & 120 & Praia da Costa & Vila Velha \\
\hline $\begin{array}{c}\text { Parque Vila Verde } \\
\text { MRV }\end{array}$ & Vertical & $\begin{array}{c}\text { Recém- } \\
\text { construido* }\end{array}$ & Sim & 300 & Planície da Serra & Serra \\
\hline Reserva Verde & Cyrela/Incortel & Vertical & Construção* & Não & 220 & Santa Luzia & Serra \\
\hline $\begin{array}{c}\text { Residencial Via } \\
\text { Garden }\end{array}$ & Cobra & Vertical & Construção & Sim & 128 & Marcilio de & Viana \\
\hline $\begin{array}{c}\text { The One Fist Class } \\
\text { Residence }\end{array}$ & Quintela Torres & Vertical & Construção & Não & 32 & Praia do Canto & Vitória \\
\hline Vila Alpina & Galwan & Vertical & Construção* & Não & 150 & Barro vermelho & Vitória \\
\hline Vila Imperial & MRV & Vertical & Construção & Sim & 420 & Santana/Tabajara & Cariacica \\
\hline Vila Platina & MRV & Vertical & Construção & Sim & 310 & Tiradentes & Cariacica \\
\hline Total & & & & 2.039 & & \\
\hline
\end{tabular}

*Empreendimentos que já possuem moradores.

Fonte: trabalhos de campo e site das empresas.

Verificado as características gerais dos empreendimentos (cf. quadro 01), passamos agora a analisar os atributos que fazem parte da construção dos mesmos, como os respectivos preços médios de vendas das unidades, área construída, área do terreno, tamanho e quantidade de plantas. Essas informações foram reunidas para serem nossos subsídios para verificarmos por meio de alguns cálculos os custos da construção (considerando o preço do terreno, o preço da mão de obra e dos materiais de construção), os lucros obtidos pelos promotores imobiliários, o papel desempenhado pelo terreno e pelo proprietário fundiário no processo da construção, a exploração do trabalho e consequentemente os rebatimentos destes processos na produção do espaço urbano. No quadro 02 podem ser verificadas detalhadamente essas informações. 


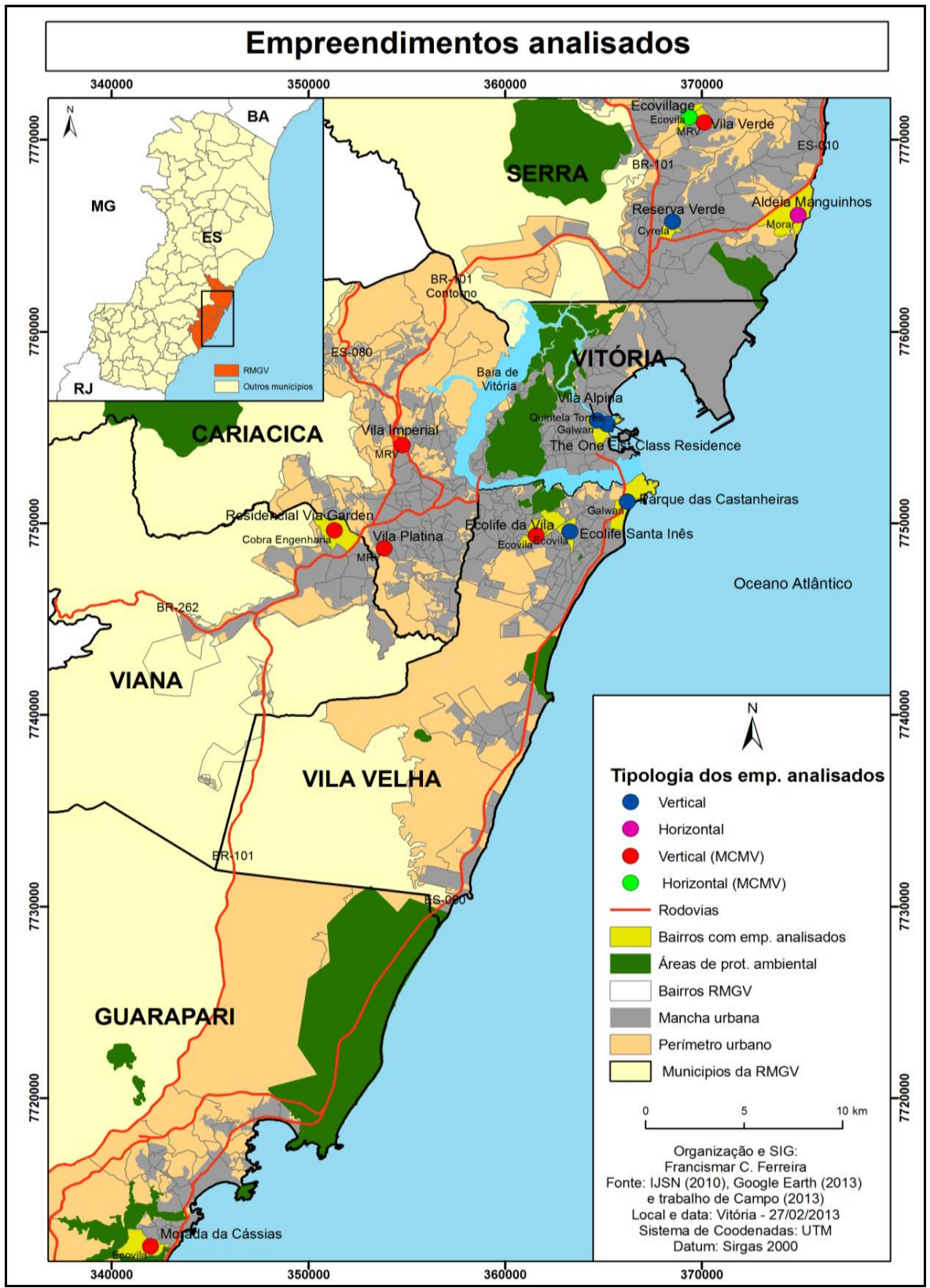

Figura 02: localização e tipologia dos empreendimentos analisados. 
Quadro 02: Preço médio de venda das unidades, área construída, área do terreno, tamanho médio das plantas, preço médio dos terrenos no entorno dos empreendimentos analisados e custo de construção do $\mathrm{m}^{2}$ (CUB).

\begin{tabular}{|c|c|c|c|c|c|c|c|}
\hline $\begin{array}{c}\text { Empreendimento } \\
\text { analisados }\end{array}$ & $\begin{array}{l}\text { Preço } \\
\text { médio das } \\
\text { unidades } \\
(R \$)^{* * * *}\end{array}$ & $\begin{array}{c}\text { Área } \\
\text { média das } \\
\text { unidades } \\
\left(\mathrm{m}^{2}\right)\end{array}$ & $\begin{array}{c}\text { Preço } \\
\text { médio do } \\
\mathrm{m}^{2} \text { de } \\
\text { venda das } \\
\text { unidades }\end{array}$ & $\begin{array}{c}\text { Área } \\
\text { construída } \\
\left(\mathrm{m}^{2}\right)\end{array}$ & $\begin{array}{c}\text { Área do } \\
\text { terreno } \\
\left(\mathrm{m}^{2}\right)\end{array}$ & 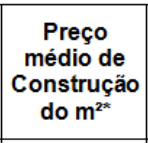 & \begin{tabular}{|c} 
Preço médio \\
do $\mathrm{m}^{2}$ \\
terrenos no \\
entorno dos \\
emp.
\end{tabular} \\
\hline $\begin{array}{c}\text { Aldeia } \\
\text { Manguinhos }\end{array}$ & 658.000 & 163 & $4.036,8$ & 10.269 & $21.556,79$ & $1.145,38$ & 674,67 \\
\hline Ecolife da Vila & 150.500 & 48,43 & 3.107 .58 & $2.905,8^{\star \star}$ & 1.216 & $1.145,38$ & 494,69 \\
\hline $\begin{array}{c}\text { Ecolife Santa } \\
\text { Inês }\end{array}$ & 195.000 & 56 & $3.482,15$ & $1.904^{\star \star}$ & 630 & $1.145,38$ & 494,69 \\
\hline Ecovillage & 170.000 & 61 & $2.786,88$ & $1.586^{\star \star}$ & $2.731,65$ & $1.145,38$ & 445,4 \\
\hline $\begin{array}{c}\text { Morada das } \\
\text { Cássias }\end{array}$ & 112.500 & 47 & $2.393,61$ & $8.272^{\star \star}$ & 6.836 & $1.145,38$ & 164,08 \\
\hline $\begin{array}{c}\text { Parque das } \\
\text { Castanheiras }\end{array}$ & 760.125 & 163,5 & $4.649,08$ & 38.705 & 4.100 & $1.145,38$ & 1403,03 \\
\hline $\begin{array}{c}\text { Parque Vila } \\
\text { Verde }\end{array}$ & 123.000 & 47,5 & $2.589,47$ & $14.250^{* \star}$ & $13.070,66$ & $1.145,38$ & 445,4 \\
\hline Reserva Verde & $429.864,62$ & 93 & $4.622,2$ & $20.460 * *$ & 10.291 & $1.145,38$ & 462,16 \\
\hline \begin{tabular}{|c|}
$\begin{array}{c}\text { Residencial Via } \\
\text { Garden }\end{array}$ \\
\end{tabular} & $97.500^{\star \star \star *}$ & 40,9 & $2.383,86$ & $6.644,98$ & 5.696 & $1.145,38$ & 98,13 \\
\hline $\begin{array}{c}\text { The One Fist } \\
\text { Class Residence } \\
\end{array}$ & 170.0000 & 167 & $10.179,64$ & $5.344^{\star \star}$ & 1.000 & $1.145,38$ & 3.420 .83 \\
\hline Vila Alpina & 255.0000 & 289,5 & $8.808,3$ & 64.198 & 14.400 & $1.145,38$ & 3.420 .83 \\
\hline Vila Imperial & 126.000 & 47 & $2.680,85$ & 21.109 & $17.579,8$ & $1.145,38$ & 151,43 \\
\hline Vila Platina & 128.000 & 47 & $2.723,4$ & $15.560,93$ & $12.818,45$ & $1.145,38$ & 351,25 \\
\hline
\end{tabular}

Fonte: trabalho de campo, sites das empresas construtoras-incorporadoras, site de empresas de corretagem de imóveis e SINDUSCON-ES (2014).

* Preço médio do custo de construção do $\mathrm{m}^{2}$ baseado no CUB de Fevereiro de 2014.

** A área construída foi obtida pela multiplicação entre o tamanho médio das plantas dos imóveis pelo número de unidades total do empreendimento.

*** Preço obtido a partir de reportagem do caderno de imóveis do jornal Folha Vitória disponível em http://www.folhavitoria.com.br/site/?target=noticia_imprime\&cid=3\&nid=433562. Acessado em: 03/02/2014.

**** Não leva em consideração as taxas e impostos sobre as vendas, nem os juros dos financiamentos. Além disso, deve-se considerar que esses valores são oriundos dos anúncios e também do que os corretores informaram o que necessariamente pode não ser o preço real da negociação imobiliária.

Uma precisão sobre os dados do quadro 02 importante de ser considerado é o custo unitário básico da construção (CUB). O CUB conforme o SINDUSCON-ES é um indicador que tem por objetivo apontar o custo do metro quadrado da construção. É um dado que apresenta o custo parcial e não total da construção, pois, na composição do cálculo do CUB, alguns atributos da construção de empreendimentos para o mercado não são considerados, como por exemplo, os custos inerentes a terrenos, fundações especiais, elevadores, instalações de incêndio, ar condicionado, playgrounds, recreação, ajardinamento, ligações de serviços públicos, corretagem e publicidade, entre outros (SINDUSCON-ES, 2014). Esses aspectos demonstram uma limitação do indicador. O CUB é um índice divulgado mensalmente pelos SINDUSCONS estaduais que apontam os preços dos materiais de construção, de mão de obra, com alguns equipamentos utilizados na construção e, finalmente, com despesas administrativas. Além disso, o 
cálculo do índice é dividido em segmentos. No caso da produção residencial, os preços são discriminados entre os segmentos de baixo padrão, médio padrão e alto padrão. A divisão por segmentos é feita a partir de diferentes fatores, dentre eles o padrão de acabamento da construção. Entretanto, devido às dificuldades de se analisar os padrões de acabamento dos empreendimentos analisados, optamos neste trabalho por adotar o preço médio do custo da construção. Neste sentido, adotamos o preço médio do custo da construção referente ao mês de fevereiro de 2014. Na figura 03 podem ser verificados o valor do CUB e sua composição.

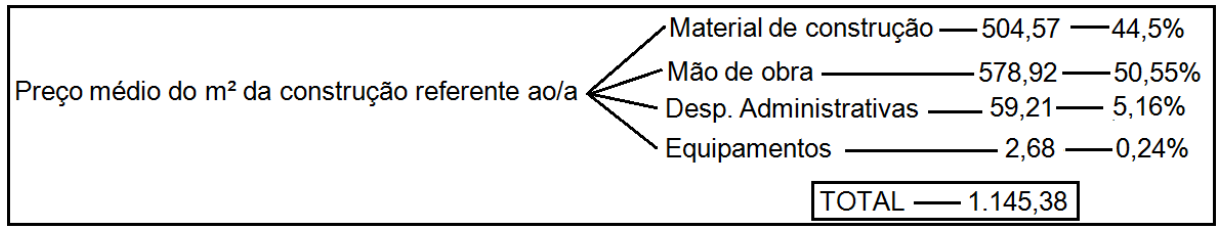

Figura 03: Composição do custo do $\mathrm{m}^{2}$ CUB de Fevereiro de 2014. Fonte: SINDUSCON-ES, 2014.

Delineadas as características do CUB e dos empreendimentos em geral, passaremos agora para a elaboração de alguns cálculos com os dados apresentados para a partir de então tornar visível algumas relações entre a produção imobiliária, a propriedade da terra e o trabalho.

Inicialmente, a partir dos dados, podemos: a) conhecer os possíveis preços dos terrenos dos empreendimentos analisados por meio da multiplicação do preço médio do $\mathrm{m}^{2}$ dos terrenos que se localizam no entorno dos empreendimentos analisados pela área do terreno do empreendimento; b) os custos totais de construção, obtido pela soma do resultado da multiplicação entre a área construída com o preço de construção do $\mathrm{m}^{2}$ somado ao preço do terreno do empreendimento; c) os valores totais de vendas dos imóveis, são obtidos pela multiplicação entre o preço médio das unidades pelo número de unidades dos empreendimentos e; d) os lucros dos promotores imobiliários foram obtidos por meio da subtração dos custos totais de construção dos valores totais de venda dos imóveis. Em síntese temos as seguintes equações:

- Preços dos Terrenos $(\mathbf{P T})=$ preço médio do $\mathrm{m}^{2}$ dos terrenos que se localizam no entorno dos empreendimentos analisados (PMm²TEA) $\mathrm{x}$ área do terreno do empreendimento (ATE); (PT = PMm²TEA x ATE).

- Custo da construção sem contabilizar os gastos com o terreno (CCST) = Área construída (AC) x custo de construção do m² (CUB); (CCST = AC x CUB).

- Custos totais de construção (CTC) = (área construída $\mathrm{x}$ custo de construção do $\left.\mathrm{m}^{2}\right)(\mathrm{AC} \times \mathrm{CUB})+$ preço dos terrenos dos empreendimentos $(\mathrm{PTE}) ;(\mathrm{CTC}=(\mathrm{AC} \mathrm{x}$ CUB) + PTE). 
- Valores totais de vendas dos imóveis (VTV) = preço médio de venda das unidades (PMVU) x número de unidades dos empreendimentos (NUE); (CTV = PMVU x NUE).

- Lucro do promotor imobiliário (LPI) = custos totais de construção (CTC) valores totais de vendas dos imóveis (VTV); (PPI = CTC - VTV).

Em relação ao cálculo do custo da construção sem a contabilização dos gastos com o terreno, é necessário salientar que a partir da mesma equação, é possível verificar o custo com a mão de obra na construção (capital variável) e também os custos com os materiais de construção, despesas com equipamentos e administração (capital constante). Para isso, se repete a equação substituindo apenas o preço médio total do CUB pelos respectivos preços médios totais dos diferentes itens que compõem o CUB que são os valores referentes à mão de obra, material de construção, equipamentos e despesas administrativas. Os resultados de todos os cálculos encontram-se no quadro 03.

Quadro 03: Preço total do terreno, custo da construção sem o terreno, custo da mão de obra, custos com material de construção equipamentos e despesas administrativas, custo total da construção, valores totais dos imóveis e lucros do promotor imobiliário.

\begin{tabular}{|c|c|c|c|c|c|c|c|c|c|c|c|c|c|c|}
\hline Empreendimento & $\begin{array}{l}\text { (I) } \\
\text { Preco total } \\
\text { do terreno } \\
\text { (PT) }\end{array}$ & $\begin{array}{c}\text { (II) }= \\
\text { (IIa + Ilb) } \\
\text { Custo da } \\
\text { construção } \\
\text { sem o terreno } \\
\text { (CCST) }\end{array}$ & $\begin{array}{c}\text { (lla) } \\
\text { Custos com } \\
\text { mão de obra } \\
\text { na } \\
\text { construção }\end{array}$ & $\begin{array}{l}\text { (llb) } \\
\text { Custos com } \\
\text { mat. De } \\
\text { construçäo, } \\
\text { equip. ed. } \\
\text { adm. }\end{array}$ & $\begin{array}{c}\text { (III) } \\
\text { (l+lli) } \\
\text { Custo total de } \\
\text { construcão } \\
\text { (CTC) }\end{array}$ & $\begin{array}{c}\text { (I IIII) } \\
\% \text { do } \\
\text { terreno no } \\
\text { custo total } \\
\text { da } \\
\text { construçäo }\end{array}$ & \begin{tabular}{|c|} 
(lla/llI) \\
$\%$ do custo \\
da mão de \\
obra no \\
custo total \\
da \\
construção
\end{tabular} & \begin{tabular}{c|} 
(IIb/III) \\
\% Custos \\
com mat. De \\
construção, \\
equip. e D. \\
Adm no custo \\
total da \\
construção. \\
\end{tabular} & $\begin{array}{c}\text { (IV) } \\
\text { Valor total } \\
\text { de vendas } \\
\text { dos } \\
\text { imóveis* } \\
\text { (VTV) }\end{array}$ & $\begin{array}{l}\text { (V) } \\
\text { (VTV-CTC) } \\
\text { Lucro do } \\
\text { promotor } \\
\text { imobiliário } \\
\text { (LPI) }\end{array}$ & \begin{tabular}{|c|} 
(VIIV) \\
\% Lucro \\
do \\
promotor \\
imobiliário \\
em relaçäo \\
ao valor de \\
venda \\
\end{tabular} & $\begin{array}{c}\text { (IIV) } \\
\% \text { do } \\
\text { terreno } \\
\text { no valor } \\
\text { total de } \\
\text { venda }\end{array}$ & \begin{tabular}{|c|} 
(lla/IV) \\
$\%$ do \\
custo da \\
mão de \\
obra no \\
valor \\
total de \\
venda \\
\end{tabular} & \begin{tabular}{|c|} 
(Ilb/lV) \\
\% Custos \\
com mat. de \\
construçäo, \\
equip. e \\
despesas \\
adm. no \\
valor total de \\
venda \\
\end{tabular} \\
\hline Aldeia Manguinhos & 14.543 .719 & 11.761 .907 & 5.945 .644 & 5.816 .263 & 26.305 .626 & 55 & 23 & 22 & 41.454 .000 & 15.148 .374 & 37 & 35 & 14 & 14 \\
\hline Ecolife da Vila & 601.543 & 3.328 .245 & 1.682 .428 & 1.645 .817 & 3.929 .788 & 15 & 43 & 42 & 9.030 .000 & 5.100 .212 & 56 & 7 & 19 & 18 \\
\hline Ecolife Santa Inês & 311.655 & 2.180 .804 & 1.102 .396 & 1.078 .407 & 2.492 .458 & 13 & 44 & 43 & 6.630 .000 & 4.137 .542 & 62 & 5 & 17 & 16 \\
\hline Ecovillage & 1.216 .677 & 1.816 .573 & 918.277 & 898.295 & 3.033 .250 & 40 & 30 & 30 & 4.420 .000 & $1.386 .750,5$ & 31 & 28 & 21 & 20 \\
\hline Morada das Cássias & 1.121 .651 & 9.474 .583 & 4.789 .402 & 4.685.181 & 10.596 .234 & 11 & 45 & 44 & 19.800 .000 & 9.203 .766 & 46 & 6 & 24 & 24 \\
\hline $\begin{array}{c}\text { Parque das } \\
\text { Castanheiras }\end{array}$ & 5.752 .423 & 44.331 .932 & 22.409 .792 & 21.922 .140 & 50.084 .355 & 11 & 45 & 44 & 91.215 .000 & 41.130 .645 & 45 & 6 & 25 & 24 \\
\hline Parque Vila Verde & 5.821 .672 & 16.321 .665 & 8.250 .602 & 8.071 .063 & 22.143 .337 & 26 & 37 & 36 & 36.900 .000 & $14.756 .663,1$ & 40 & 16 & 22 & 22 \\
\hline Reserva Verde & 4.756 .089 & 23.434 .474 & 11.846 .127 & 11.588 .347 & 28.190 .563 & 17 & 42 & 41 & 94.570 .216 & $66.379 .653,5$ & 70 & 5 & 13 & 12 \\
\hline $\begin{array}{l}\text { Residencial Via } \\
\text { Garden }\end{array}$ & 558.948 & 7.611 .027 & 3.847 .374 & 3.763 .653 & 8.169 .976 & 7 & 47 & 46 & 12.480 .000 & 4.310 .025 & 35 & 4 & 31 & 30 \\
\hline $\begin{array}{c}\text { The One Fist Class } \\
\text { Residence }\end{array}$ & 3.420 .830 & 6.120 .911 & 3.094 .120 & 3.026 .790 & 9.541 .741 & 36 & 32 & 32 & 54.400 .000 & $44.858 .259,3$ & 82 & 6 & 6 & 6 \\
\hline Vila Alpina & 49.259 .952 & 73.531 .105 & 37.169 .974 & 36.361 .131 & 122.791 .057 & 40 & 30 & 30 & 382.500 .000 & 259.708 .943 & 68 & 13 & 10 & 10 \\
\hline Vila Imperial & 2.662 .109 & 3.068 .882 & 1.551 .320 & 1.517 .562 & 5.730 .992 & 46 & 27 & 26 & 52.920 .000 & $47.189 .008,5$ & 89 & 5 & 3 & 3 \\
\hline Vila Platina & 4.502 .481 & 17.832 .178 & 9.014 .166 & 8.818 .012 & 22.334 .659 & 20 & 40 & 39 & 39.680 .000 & $17.345 .341,5$ & 44 & 11 & 23 & 22 \\
\hline Tot & 94.5 & 36 & 111 & 109. & 034 & 30 & 35 & 35 & 845.99 & 338.739 .506 & 40 & 11 & 13 & 13 \\
\hline
\end{tabular}

Fonte: Trabalhos de campos, site das empresas incorporadoras/construtoras dos empreendimentos, SINDUSCON-ES (2014) e jornais A Gazeta e A Tribuna (entre os dias 23 de janeiro e 28 de março de 2013).

Inicialmente, estudando o quadro 03, podemos verificar a real participação do preço do terreno (renda da terra), dos custos referentes ao material de construção, equipamentos e despesas administrativas que correspondem ao capital constante e o custo da mão de obra correspondente capital variável no custo da construção segundo a terminologia marxista. Verifica-se que em quatro empreendimentos (Vila Imperial, Ecovillage, Aldeia de Manguinhos e Vila Alpina) o preço da terra corresponde proprorcionalmente ao maior custo na construção. Em relação ao capital variável, nota-se que em oito empreendimentos (Vila Platina, Morada das Cássias, Parque Vila Verde, Reserva Verde, Via Garden, Parque das Castanheiras, Ecolife da Vila e 
Ecolife Santa Inês) ele representa o maior custo proporcional na construção e que ainda é muito significativo nos empreendimentos em que os preços dos terrenos correspondem ao maior custo. Em relação aos custos dos materias de construção, equipamentos e despesas administrativas, verifica-se como sendo o elemento que aparece como sendo o segundo ou terceiro maior custo na construção. A única exeção é o empreendimento The One First Class Residence, onde os custos entre capital variável, capital constante e preço do terreno são relativamente equivalentes. Entretanto, deve-se ressaltar que em todos os empreendimentos, o capital variavel é igual ou maior do que o capital constante, quando se exclue desse último os custos com os terrenos.

A questão que surge a partir destas constatações consiste em compreender, como e porque em alguns casos, o custo do terreno que equivale a renda da terra, corresponde ao maior custo e em outros casos predomina o custo com a mão de obra no processo da construção? Inicialmente, em relação ao terreno pode ser pensado duas coisas, uma em relação a uma condição interna da construção, a área do terreno, e outra, inerente a condição externa do mesmo, em relação a localização. Quanto à área do terreno, nota-se que dos quatro empreendimentos em que o custo do terreno predomina no custo da construção, dois são horizontais (Ecovillage localizado em Porto Canoa e Aldeia Manguinhos em Manguinhos, ambos em Serra), logo demandam terrenos maiores, eles são bem maiores do que a propria área total construida dos empreendimentos (cf. quadro 02). No empreendimento Ecovillage a área construida representa $58 \%$ do terreno, no caso do Aldeia de Manguinhos, essa proprorção é de 47,6\% (cf. quadro 02). Além disso, tem-se a área do terreno do empreendimento Vila Imperial (do PMCMV localizado no bairro Santana em Cariacia), que aparece como sendo o maior terreno $\left(17.579,80 \mathrm{~m}^{2}\right)$ entre os empreendimentos verticais conforme aponta a quadro 02, e, portanto, com importante participação no custo final. Outro empreendimento, o Vila Alpina localizado no bairro Barro Vermelho em Vitória, tem influências externas a construção, onde a influência predominante do terreno deriva de sua localização produzida socialmente. Este empreendimento está localizado em um bairro próximo às praias de Vitória, onde se verifica vários equipamentos e infraestururas (equipamentos de lazer, educação, saúde, comércio e etc.)., e que apresenta uma grande produção e alta valorização imobiliára, onde os terrenos ultimamente vêm se tornando escassos para a construção. Essas e outras condições permitem que os proprietários fundiários estabeleçam altos preços pelos terrenos fazendo com que se configure uma renda diferencial ${ }^{4}$ em relação às outras localizações menos dotadas de equipamentos. Há assim, um monopólio sobre os lotes de poucos proprietários e em consequencia a imposição de um preço elevado sobre os terrenos dessas localizações.

\footnotetext{
${ }^{4}$ Sobre renda diferencial Harvey (1980 e 2013) e Zanotelli et. al. (2014).
} 
Em relação aos empreendimentos em que o capital variável é superior ao valor pago pelo terreno, isso pode ser de modo geral compreendido pelo fato de que os empreendimentos não se localizam em áreas onde predominam rendas de monopólio ${ }^{5}$ sobre os terrenos, mas em áreas onde o preço dos terrenos são mais baratos (as rendas diferenciais são inferiores ao centros) em relação aos locais onde predominam as rendas de monopólio. Além disso, outro fato que justifica o alto custo da mão de obra refere-se ao tamanho da área construída dos empreendimentos, em geral entre os oitos empreendimentos verificados com custo de capital variável superior ao da terra, todos possuem áreas construídas significativamente maiores do que a área do terreno. Com uma exceção, o Vila Alpina. Ele é o que possui a maior área construída entre todos os empreendimentos pesquisados $\left(64.198 \mathrm{~m}^{2}\right)$, bem superior a área do terreno, entretanto, em função de sua localização onde predomina a renda de monopólio sobre o terreno, os custos com o terreno acabaram sendo superiores ao custo com a mão de obra.

Em relação aos lucros imobiliários, analisando ainda o quadro 03, nota-se que em seis dos treze empreendimentos (Vila Imperial, Reserva Verde, Ecolife da Vila, Ecolife Santa Inês, The First One Residence e Vila Alpina) o total representou entre $56 \%$ e $89 \%$ do valor da venda e em alguns casos o lucro representou 8 vezes o custo total da construção (Vila Alpina). Demonstrando taxas de lucros exponenciais. Entretanto, para se compreender de modo mais detalhado os lucros dos promotores imobiliários, uma análise sobre a taxa de lucro, a taxa de mais valia e a taxa da renda da terra deve ser realizada para verificarmos os lucros dos promotores que derivam da exploração do trabalho e da apropriação da renda da terra. No caso da construção a terra não pode ser considerada capital constante, porque ela na construção não é meio de produção, mas condição para produção. Entretanto, o preço da terra que o incorporador paga ao proprietário fundiário faz parte do custo da construção. Neste sentido, para verificarmos os custos e os lucros da construção, a renda da terra deve ser considerada. Logo o lucro do promotor imobiliário é sensível ao preço da terra exigida pelo proprietário fundiário.

A renda da terra entra então no custo da construção e influência o lucro (mais valia) do promotor imobiliário. Assim, utilizaremos a partir de Marx (apud HARVEY, 2013a) as formas de cálculos das taxas de lucro e de mais valia. As taxas de renda da terra são um exercício que se acrescenta ao citado anteriormente para tentar comparar e tirar algumas conclusões dos dados apresentados e estudados dos empreendimentos. Estamos cientes das dificuldades que existem de definir essas taxas em um setor e em alguns empreendimentos precisos, pois a mais valia conceituada e aplicada por Marx supõe uma equalização constante da mais valia no conjunto da sociedade, o que torna seu cálculo muito difícil por empreendimento. Neste sentido, consideramos no nosso exercício:

\footnotetext{
${ }^{5}$ Sobre renda de monopólio Harvey (1980 e 2013) e Zanotelli et. al. (2014).
} 
- A taxa de mais valia como sendo o produto da divisão entre o lucro liquido pelo gasto com capital variável (Taxa de mais valia = Mais valia / capital variável (custos salariais): (TMV $=\mathrm{MV} / \mathrm{CV})$ ). A taxa de mais valia mede a relação do lucro com os custos salariais e a taxa de exploração.

- A taxa de lucro corresponde ao resultado da divisão do lucro (mais valia (MV)) pelo resultado da soma do capital variável (custos salariais) (CV) com o capital constante (custos com material de construção equipamentos e etc.) (CC) e a renda da terra (preço do terreno) (RT) (Taxa de lucro = mais valia / (capital constante + capital variável + renda da terra (preço do terreno) $(\mathrm{TL}=$ $\mathrm{MV} /(\mathrm{CC}+\mathrm{CV}+\mathrm{RT}))$. A taxa de lucro mede a relação do lucro com as despesas totais (equipamentos, custos salariais) à qual se acrescenta o custo da terra.

- $\quad$ Em relação à taxa da renda da terra (TRT), consideramos a relação entre a mais valia e o preço pago ao terreno que corresponde à renda da terra paga pelo promotor imobiliário ao proprietário fundiário (taxa de renda da terra = mais valia (lucro) / renda da terra (preço do terreno) $(\mathrm{TRT}=\mathrm{MV} / \mathrm{RT}))$. A taxa de renda da terra mede a relação do lucro com o preço da terra, e, portanto, do sobrelucro relativo à terra, que no nosso caso representa a proporção de lucro não pago ao dono da terra, pois, o promotor imobiliário ou comprou a terra barata ou a vende junto com as transformações operadas no terreno muito cara.

No quadro 04 e na figura 04 , podem ser verificados os resultados dos cálculos das taxas para cada empreendimento analisado.

Quadro 04: Taxa de lucro, de mais valia e renda da terra.

\begin{tabular}{|c|c|c|c|c|c|c|c|}
\hline Empreendimentos & Bairro & $\begin{array}{c}\text { Número } \\
\text { de } \\
\text { unidades }\end{array}$ & $\begin{array}{c}\text { Ärea } \\
\text { construída } \\
\left(\mathrm{m}^{2}\right)\end{array}$ & $\begin{array}{c}\text { Arrea do } \\
\text { terreno } \\
\left(\mathrm{m}^{2}\right)\end{array}$ & $\begin{array}{c}\text { Taxa de } \\
\text { renda da } \\
\text { terra }\end{array}$ & $\begin{array}{c}\text { Taxa } \\
\text { de } \\
\text { mais } \\
\text { valia }\end{array}$ & $\begin{array}{c}\text { Taxa de lucro } \\
\text { considerando } \\
\text { a terra }\end{array}$ \\
\hline $\begin{array}{c}\text { Aldeia } \\
\text { Manguinhos }\end{array}$ & Manguinhos / Serra & 63 & 10.269 & 21.557 & 1,04 & 2,55 & 0,58 \\
\hline Ecolife da Vila* & Ataide/ Vila Velha & 60 & 2.906 & 1.216 & 8,48 & 3,03 & 1,3 \\
\hline Ecolife Santa Inês & $\begin{array}{c}\text { Santa Inês / Vila } \\
\text { Velha }\end{array}$ & 34 & 1.904 & 630 & 13,28 & 3,75 & 1,66 \\
\hline Ecovillage $^{*}$ & Porto Canoa / Serra & 26 & 1.586 & 2.732 & 1,14 & 1,51 & 0,46 \\
\hline $\begin{array}{c}\text { Morada das } \\
\text { Cássias }\end{array}$ & $\begin{array}{l}\text { Kubistchek } \\
\text { /Guarapari }\end{array}$ & 176 & 8.272 & 6.836 & 8,21 & 1,92 & 0,87 \\
\hline $\begin{array}{l}\text { Parque das } \\
\text { Castanheiras }\end{array}$ & $\begin{array}{c}\text { Praia da Costa/ Vila } \\
\text { Velha }\end{array}$ & 120 & 38.705 & 4.100 & 7,15 & 1,84 & 0,82 \\
\hline $\begin{array}{l}\text { Parque Vila } \\
\text { Verde* }\end{array}$ & $\begin{array}{c}\text { Planície da Serra / } \\
\text { Serra }\end{array}$ & 300 & 14.250 & 13.071 & 2,53 & 1,79 & 0,67 \\
\hline Reserva Verde & Santa Luzia / Serra & 220 & 20.460 & 10.291 & 13,96 & 5,6 & 2,35 \\
\hline $\begin{array}{c}\text { Residencial Via } \\
\text { Garden* }\end{array}$ & \begin{tabular}{|l|} 
Marcilio de Noronha \\
/ Viana
\end{tabular} & 128 & 6.645 & 5.696 & 7,71 & 1,12 & 0,53 \\
\hline $\begin{array}{c}\text { The One Fist } \\
\text { Class Residence }\end{array}$ & $\begin{array}{c}\text { Praia do Canto / } \\
\text { Vitória }\end{array}$ & 32 & 5.344 & 1.000 & 13,11 & 14,5 & 4,7 \\
\hline Vila Alpina & $\begin{array}{c}\text { Barro vermelho / } \\
\text { Vitória }\end{array}$ & 150 & 64.198 & 14.400 & 5,27 & 6,99 & 2,12 \\
\hline Vila Imperial $^{*}$ & $\begin{array}{c}\text { Santana/Tabajara / } \\
\text { Cariacica }\end{array}$ & 420 & 21.109 & 17.580 & 17,73 & 30,42 & 8,23 \\
\hline Vila Platina* & $\begin{array}{l}\text { Tiradentes / } \\
\text { Cariacica }\end{array}$ & 310 & 15.561 & 12.818 & 3,85 & 1,92 & 0,78 \\
\hline Total & & 2039 & 211.209 & 111.926 & 3,58 & 3,03 & 1,07 \\
\hline
\end{tabular}

*Empreendimentos enquadrados no PMCMV. / Maiores valores

Fonte: Trabalhos de campos, site das empresas incorporadoras/construtoras dos empreendimentos e SINDUSCON-ES (2014). 
Em relação às taxas, é importante destacar que quanto mais próximo de 1, as taxas de mais valia, as taxas de lucro e as taxas de renda da terra são baixas, o lucro tende a se igualar respectivamente ao custo da força de trabalho, ao custo total ou ao custo do terreno; quanto maior for a taxa, mais ela se destaca, assim, uma taxa de mais valia igual a 2 equivale a um lucro que representa duas vezes o que se gastou com os custos salariais

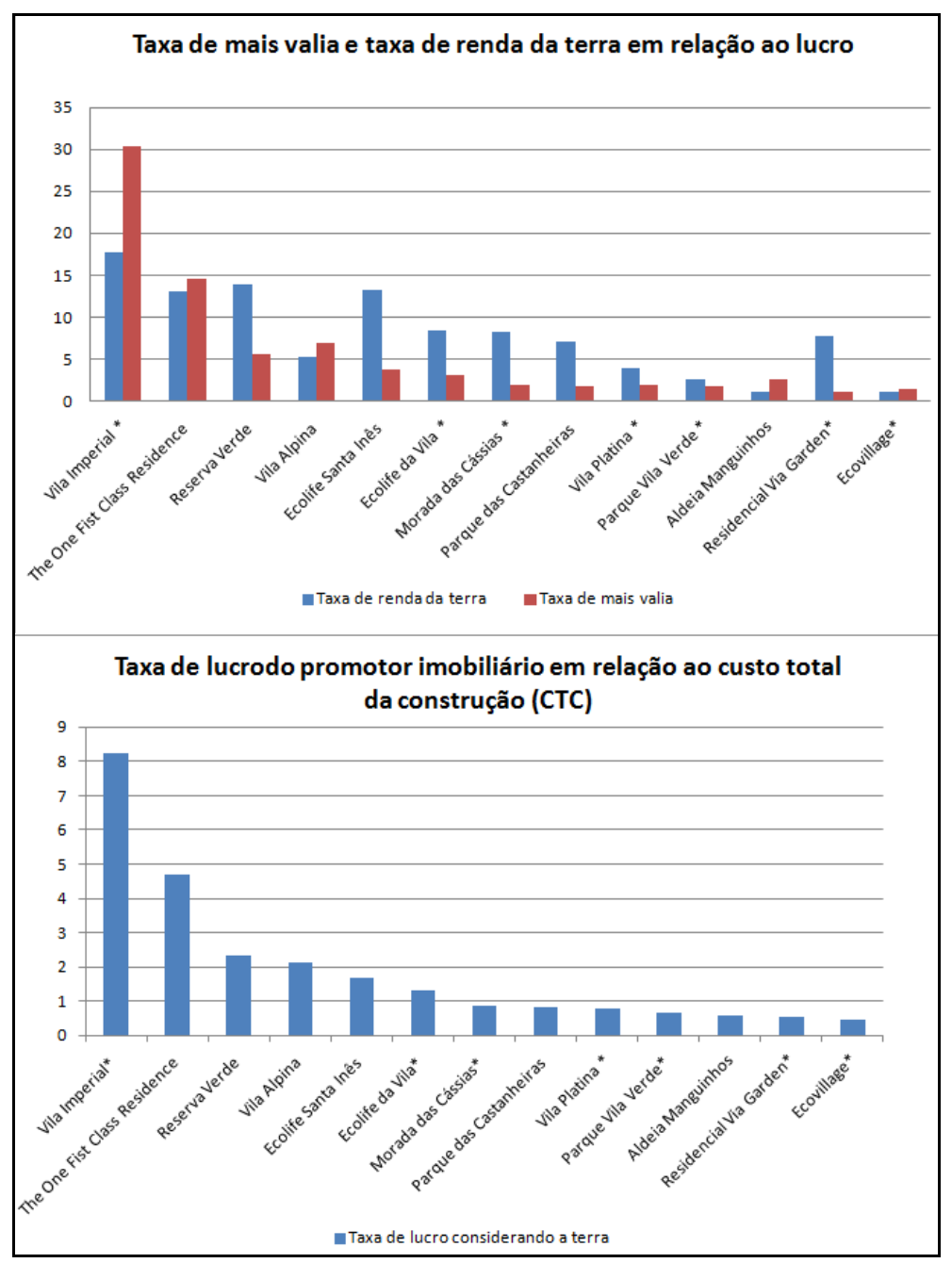

Figura 04: Gráficos da taxa de mais valia, renda da terra e de lucro.

*Empreendimentos enquadrados no PMCMV.

Fonte: Trabalhos de campos, site das empresas incorporadoras/construtoras dos empreendimentos e SINDUSCON-ES (2014). 
Analisando o quadro 04 e a figura 04 podemos notar que, a taxa de renda da terra varia de 1 a 17, a taxa de mais valia vai de 1 a 30 e a taxa de lucro de 1 a 8 . Em quatro casos, a taxa de renda da terra é superior a taxa de mais valia, demonstrando uma relação de extração de lucro da terra em geral superior a extração de lucro pelo trabalho, seja porque a relação do preço pago pelo terreno é bem inferior ao preço do mercado, ou ainda porque o preço de venda (preço de monopólio) é proporcionalmente alto ao que custou o terreno, mas também, a taxa de exploração da mais valia vai de par e passu com a taxa de renda da terra e de lucro (vide Vila imperial pelas taxas mais altas de renda da terra, mais valia e lucro).

Analisando a taxa da renda da terra (o sobrelucro retirado dos proprietários fundiários) nota-se que os dois empreendimentos horizontais (Ecovillage e Aldeia Manguinhos) são os que apresentam as menores taxas. O Ecovillage tem uma taxa de renda da terra de 1,14, ou seja, o lucro equivale ao que custou o terreno, enquanto que o Aldeia Manguinhos apresenta uma taxa de renda da terra é 1,04. Nestes dois casos a taxa de renda da terra é inferior à taxa de mais valia, ou seja, a relação do lucro com os gastos salariais é mais significativa que com os gastos com a terra. Além desses casos, outros três empreendimentos possuem a taxa de renda da terra inferior à taxa de mais valia que são os casos dos empreendimentos The One First Class Residence, Vila Alpina e Vila Imperial. No caso dos dois primeiros empreendimentos, o que, em parte, justifica a taxa de renda da terra inferior à taxa de mais valia é o fato dos mesmos estarem localizados (respectivamente Praia do Canto e Barro Vermelho em Vitória) em bairros onde se verifica o preço médio do metro quadrado de terrenos mais caro dentre os empreendimentos analisados. Além disso, a relação do lucro com os custos salariais é um pouco superior aquela da relação com o custo dos terrenos. Por sua vez, a situação do Vila Imperial é diferente, o preço médio do metro quadrado do terreno não é tão caro como o dos casos anteriores, entretanto a questão está na área construída, no número de unidades e no preço de venda da unidades do empreendimento, o que faz com que a relação lucro/custos salariais seja quase o dobro da relação lucro/terreno.

O Vila Imperial (localizado na periferia de Cariacica) é o empreendimento que apresenta a segunda maior área construída entre os empreendimentos analisados, ficando atrás somente do Vila Alpina (cf. quadro 04). Entretanto, ele é o empreendimento que apresenta o maior número de unidades, sendo 420 ao todo, contra 150 do Vila Alpina. Deste modo, pode-se dizer que o trabalho foi "mais produtivo" quando comparado ao Vila Alpina. Além disso, soma-se a questão o fato do preço de venda do empreendimento estar definido muito acima do seu custo total, o que é demonstrado pela taxa de lucro comparada ao Vila Alpina (cf. quadros 03 e 04).

Em média, os treze empreendimentos apresentam uma taxa de renda da terra correspondente a 7,96. Ou seja, quase 8 vezes maior é a relação da mais valia (lucro) com o preço da terra, demonstrando uma acentuação do sobrelucro retirado do capitalista e em última instância do trabalhador que produz o valor. 
Em relação à taxa de mais valia, que representa o trabalho não pago aos trabalhadores, nota-se que a produção imobiliária é extremamente exploradora de trabalho, em média entre os 13 empreendimentos tem-se uma taxa de exploração de aproximadamente 4,91. Ou seja, o valor da mais valia é 4,91 vezes maior do que o valor pago aos trabalhadores. O que se destaca ainda analisando o quadro 04, corresponde à taxa de mais valia verificada no empreendimento Vila Imperial do PMCMV, apresentando uma taxa de mais valia de 30,42. Essa alta taxa de mais valia se explica conforme apresentamos acima devido a grande área construída, o elevado número de unidades e o preço de venda das unidades do empreendimento, esse muito acima do preço de custo. Além disso, destaca-se ainda as taxas de mais valia do empreendimento The First One Residence (localizado no bairro Praia do Canto em Vitória), de 14,5. Essa alta taxa pode ser compreendida em função do preço de venda do empreendimento muito acima do preço de produção e ainda devido o mesmo apresentar uma área construída $\left(5.344 \mathrm{~m}^{2}\right)$ proporcionalmente muito maior do que a área do terreno $\left(1000 \mathrm{~m}^{2}\right)$. As mesmas considerações também nos ajudam a compreender a alta taxa de mais valia do empreendimento Vila Alpina (localizado no bairro Barro Vermelho em Vitória).

Por sua vez, a taxa de lucro, conforme o quadro 04, tem-se os dois empreendimentos horizontais (Aldeia Manguinhos e Ecovillage) entre as três menores taxas de lucros, o que demonstra que o alto preço por um grande terreno para a construção deste tipo de imóvel que seja enquadrado no PMCMV ou não, diminui as taxas de lucros dos promotores imobiliários. Neste sentido, pode-se levantar a hipótese de que o pequeno número de empreendimentos horizontais lançados na RMGV em relação aos empreendimentos verticais se deve ao fato de ser uma tipologia que apresenta uma taxa de lucro, de mais valia e de renda da terra menor para os incorporadores/construtores, devido à renda da terra exigida pelos proprietários de terra.

O empreendimento que apresenta a maior taxa de lucro é o empreendimento Vila Imperial inserido no PMCMV localizado em uma região periférica de Cariacica apresentando uma taxa de lucro de 8,23 seguido dos empreendimentos voltados para os segmentos econômicos médio alto e alto localizados em regiões que apresentam importante produção imobiliária, como o caso do The One First Class Residence, localizado no bairro Praia do Canto, o Reserva Verde em Santa Luzia próximo a Laranjeiras, o Vila Alpina em Barro Vermelho e o Ecolife Santa Inês no bairro Santa Inês, que junto com Ataíde, Aribiri e etc. apresentam uma grande produção imobiliária recente.

Diante das taxas apresentadas uma coisa chama a atenção, é o fato de ser um empreendimento enquadrado no PMCMV (Vila Imperial) apresentar a maior taxa de lucro ao incorporador/construtor e ao mesmo tempo apresentar a maior taxa de mais valia e maior taxa de renda da terra (cf. figura 04). Isso se deve a três coisas, uma 
primeira relacionada ao baixo preço do terreno do empreendimento que se localiza no limite dos bairros Santana e Tabajara em Cariacica ${ }^{6}$, a segunda se deve ao tamanho da área construída e o número de unidades. O empreendimento Vila Imperial apresenta como apontamos acima, a segunda maior área construída entre os empreendimentos estudados com $21.109 \mathrm{~m}^{2}$ e ainda apresenta o maior número de unidades, sendo 420 de tamanho médio de $47 \mathrm{~m}^{2}$, o que justifica em parte a alta taxa de exploração, por fim, a terceira, corresponde ao preço de venda das unidades que é definido pelo incorporador/construtor, esse, muito superior ao custo total da construção. Deste modo, somadas às particularidades do baixo preço da terra (cf. quadro 02) ao grande tamanho de área construída, ao grande número de unidades e o preço de venda muito superior ao preço de custo total da construção pode-se compreender os motivos das elevadas taxas de renda da terra, mais valia e lucro do empreendimento Vila Imperial.

Diante do exposto acima, podemos nos questionara ainda porque $o$ empreendimento Residencial Via Garden - inserido no PMCMV - que possui o $\mathrm{m}^{2}$ do terreno mais barato (cf. quadro 02), localizado no bairro Marcilio de Noronha em Viana, não possui taxas de lucro, mais valia e renda da terra tão grandes como a do empreendimento Vila Imperial? Inicialmente podemos considerar o tamanho da área construída, enquanto que o Vila Imperial apresenta uma área construída de aproximadamente 1,2 vezes maior que o terreno $\left(21.109 \mathrm{~m}^{2}\right.$ de área construída em um terreno de 17.579,8 $\mathrm{m}^{2}$ ), o Via Garden apresenta uma área construída de 1,12 vezes maior que o terreno (6.383,8 de área construída em um terreno de 5.696 m²), ou seja, proporcionalmente uma área construída pouco menor. Ainda em relação ao tamanho do empreendimento, outro atributo que justifica essas diferenças nas taxas é em relação ao número de unidade, enquanto o Vila Imperial possui 420 unidades, o Via Garden possui 128. Além disso, tem-se o fator externo novamente a construção inerente à localização, Santana está relativamente próximo ao subcentro metropolitano de Campo Grande e ao terminal rodoviários urbano de Itacibá, é cortado por uma importante via do município de Cariacica a ES-080 (José Sete), e também próximo à rodovia do Contorno (BR-101 Contorno), facilitando assim o acesso a Serra e etc. que são fatores que nos auxiliam a explicar o preço do imóvel Vila Imperial no bairro. Enquanto o Via Garden está em um município onde a produção imobiliária é ainda muito incipiente, em uma região também relativamente próxima a Campo Grande via a BR-262, mas distante de Vitória, Serra e Vila Velha. Além disso, tem-se o fato do estabelecimento do preço do empreendimento pelo incorporador/construtor, que em Viana não pode estabelecer um alto preço pelo imóvel devido dentre outras coisas a não consolidação da produção imobiliária no município, que levaria consigo uma elevação dos preços da

\footnotetext{
${ }^{6}$ Cabe ressaltar que segundo depoimento em entrevista cedida a outro pesquisador do grupo de estudos "A expansão da Região metropolitana da Grande Vitória: a terra é o nó" de uma ex-subsecretária da secretaria de planejamento urbano de Cariacica, todos os empreendimentos do PMCMV do município tiveram os terrenos indicados e/ou subvencionados pela prefeitura às empresas construtoras-incorporadoras.
} 
terra e dos imóveis, e possivelmente em decorrência de uma ausência de público consumidor para empreendimentos de valor elevado.

Em síntese, a partir da análise das taxas de lucro, mais valia e renda da terra, nota-se que essas são sensíveis às diferenças de tipologias dos empreendimentos (vertical e horizontal), ao tamanho, a localização e ao preço do terreno, ao número de unidades dos empreendimentos e ao tamanho da área construída, ao preço de venda estabelecido pelo promotor imobiliário e à exploração do trabalho. Além disso, nota-se que o lucro do promotor imobiliário ora tem maior parte advindo da taxa de renda da terra, que representa a parte do lucro não paga ao proprietário da terra como demonstra os casos dos empreendimentos Reserva Verde, Ecolife Santa Inês, Ecolife da Vila, Morada das Cássias, Parque das Castanheiras, Vila Platina, Parque Vila Verde e Residencial Via Garden que possuem taxas de renda da terra superiores às suas respectivas taxas de mais valias, e que ora o lucro do promotor imobiliário em sua maior parte advém da exploração do trabalho, como no caso dos empreendimentos Aldeia Manguinhos, Ecovillage, Vila Alpina The One First Class Residence e Vila Imperial que possuem taxas de mais valia superiores a suas taxas de renda da terra. Entretanto, existem casos onde mesmo tendo diferença entre a taxa de renda da terra e a de mais valia, as duas são elevadas, o que culmina em uma taxa de lucro fabular para os promotores imobiliários como ficou demonstrado principalmente com o empreendimento Vila Imperial.

Visto algumas considerações sobre as taxas de lucro, de renda e de mais valia, por meio de uma análise do processo da construção, algumas questões devem ser colocadas. Em princípio, como se relacionam os atores (proprietário de terra, trabalhador e promotores imobiliários) neste processo? Qual a relação entre a renda da terra com produção imobiliária? Como é definido o preço dos imóveis, que consequentemente influência na determinação do lucro imobiliário?

Em relação aos atores envolvidos na construção ${ }^{7}$, os promotores imobiliários têm um papel destacado, isso, pois são eles que vão conduzir o processo da construção. Serão eles os responsáveis pela concepção do empreendimento, pela definição da localização, pela avaliação do mercado, da contratação de serviços, articulação com instituições para a viabilização de financiamentos e etc. (RIBEIRO apud GONÇALVES 2010). O proprietário de terra apenas participa do processo, pois detém por direitos jurídicos a propriedade privada da terra, essa que é condição para a produção imobiliária. Entretanto, para que o promotor imobiliário tenha acesso a terra, ele deve pagar uma renda da terra ao proprietário de terra ${ }^{8}$. Neste sentido, esta renda da terra pode se apresentar como uma barreira para a indústria da construção. De modo

\footnotetext{
${ }^{7}$ Cabe ressaltar que além desses atores, existem ainda na construção outros também importantes, como por exemplo, a participação dos Bancos no financiamento da construção e do consumo.

${ }^{8}$ Evidentemente, que associações entre os proprietários de terra e a indústria da construção podem ser feitas e nesse contexto a renda da terra passa a ser disputado entre ambos, o que evidencia assim que o proprietário de terra não disponibiliza a terra para a construção sem cobrar uma renda.
} 
geral, o promotor imobiliário acaba tendo que pagar uma renda da terra (representada pelo preço da terra) ao proprietário da terra. Neste sentido devemos perguntar o que vem a ser a renda da terra?

A renda da terra, a partir das perspectivas apontadas por Marx (1988) e Harvey (1980 e 2013), de maneira geral, se apresenta como sendo uma parte do mais valia social, da qual os proprietários de terra se apropriam, devido à existência da propriedade privada da terra, meio de produção não produzido, limitado, não reprodutível. Neste contexto sendo a renda da terra mais valia, devemos novamente nos questionar, de onde e como surge a mais valia que o promotor imobiliário "utiliza" para pagar a renda.

Em geral, a mais valia utilizada pelo promotor imobiliário para o pagamento da renda ao proprietário de terra surge de sua relação com o trabalho no processo da construção. Isso, pois, para o promotor imobiliário produzir uma edificação, não basta somente o terreno e os materiais de construção, é necessário também a força de trabalho. Neste sentido, os promotores imobiliários passam a depender da força de trabalho e a compram. Mas, no ato da compra, estabelece-se uma espécie de contrato entre o trabalhador e o promotor imobiliário ou um capitalista qualquer, que determinam duas condições. Uma primeira, que o trabalhador irá trabalhar sob o controle de quem comprou sua força de trabalho, e a segunda, que tudo que o trabalhador produzir durante o tempo que foi contratado será do promotor imobiliário. Em troca, o promotor imobiliário lhe fornecerá o pagamento na forma de salário (HARVEY, 2013). A partir disso, o trabalho é organizado para produzir uma nova mercadoria a partir mercadorias adquiridas (terreno e materiais de construção) pelo promotor imobiliário para a construção. E essa nova mercadoria (o produto imobiliário) terá um valor maior, pois, para produzi-la, um determinando tempo de trabalho teve que ser empregado nas outras mercadorias (terreno e material de construção). E o tempo de trabalho gera valor. Entretanto, o trabalho produz valor acima do equivalente ao necessário para a sua reprodução, isso, pois, se são necessárias 5 horas de trabalho para se produzir um valor equivalente a sua reprodução que é pago na forma de salário, o capitalista o contrata por 10 horas, e consequentemente se apropria de 5 horas de valor produzido na forma trabalho excedente. Deste modo, surge à conhecida mais valia, fruto da diferença entre o valor que o trabalho incorpora nas mercadorias numa jornada de trabalho e o valor que o trabalhador recebe por entregar ao capitalista a força de trabalho em troca do salário (HARVEY, 2013).

Diante disto, pode-se concluir que todo valor é produzido pelo trabalho e toda mais valia corresponde a tempo de trabalho não pago (HARVEY, 2013). Deste modo, sendo a renda da terra mais valia, e quem paga a renda da terra é o capitalista que em nosso caso se personifica na figura do promotor imobiliário, pode-se concluir que a renda da terra paga ao proprietário de terra se configura como sendo uma parcela da mais valia que surgiu do trabalho não pago na construção. 
Visto como se relacionam os atores envolvidos na construção, resta-nos entender como é definido o preço dos imóveis e a relação entre a renda da terra e a produção imobiliária. Neste sentido, partimos do pressuposto de que as mercadorias, de maneira geral, são comercializadas tendo como base o preço médio de produção, ou seja, o custo de produção (capital constante mais o capital variável) acrescido da taxa de lucro médio. As mercadorias da construção apresentam uma particularidade, pois somam-se ao custo da produção acrescido da taxa de lucro médio, o preço pago pela terra - a renda da terra que a indústria da construção pagou para algum agente que exerce o controle sobre uma determinada porção de terra. Assim, podemos apontar, de maneira sumária, que o preço de produção na construção (PPC) é o capital constante (CC) mais o capital variável (CV) mais taxa média de lucro (TL) e mais a renda da terra $(\mathrm{RT})(\mathrm{PPC}=\mathrm{CC}+\mathrm{CV}+\mathrm{TL}+\mathrm{RT})($ FERREIRA, 2015).

Esse pensamento é, em certa medida, válido para a produção que se realiza a preço de custo, onde a indústria da construção apenas se apropriou da taxa de lucro médio. Entretanto, nossos estudos sobre as taxas de lucros dos empreendimentos nos demostraram que essas são elevadas. Verificamos casos de taxas de lucros acima de 8 (Vila Imperial), ou seja, um lucro da indústria da construção 8 vezes maior que os gastos com o capital constante, capital variável e renda da terra; logo, a indústria da construção não comercializa seu produto pelo preço de custo.

O preço das mercadorias da construção diante do exposto não se realiza nos limites do preço de produção da construção $(\mathrm{PPC}=\mathrm{CC}+\mathrm{CV}+\mathrm{TL}+\mathrm{RT})$. Existe outra coisa que condiciona o preço dos imóveis, e ela se particulariza por ser externa ao processo da construção, pois não é verificada entre os componentes do preço de produção da construção. Essa outra coisa é a renda cobrada pela indústria da construção por uma determinada fração de espaço em uma localização singular em um determinado contexto (espacial e temporal) da Divisão Econômica e Social do Espaço (DESE) (LIPIETZ, 1985). Uma localização específica pode vir a ter investimentos de capital fixo, melhorias no sistema de transporte, pode sofrer modificações dos possíveis usos, etc. Esses possíveis acontecimentos, somados a outros, fazem com que constantemente os preços dos imóveis sofram oscilações. Um prédio ou uma casa antiga, por exemplo, pode vir a ter variação no seu preço (positivo ou negativo) em função das dinâmicas da localização e até mesmo de todo o contexto urbano (FERREIRA, 2015).

Tal processo nos permite apontar que o preço das mercadorias da construção, além de ser formada pelo preço de produção somado à renda (PPC = $\mathrm{CC}+\mathrm{CV}+\mathrm{TL}+\mathrm{RT}$ ), "também se origina de uma alteração de valores fora da unidade produtiva como renda imobiliária" (TONE, 2010, p. 57), ou seja, provém do contexto da localização, que é externa a construção de um produto em si, que é prenhe de uma gama de usos futuros possíveis. 
Diante disto, podemos apontar que o preço de um produto imobiliário, que evidencia a relação entre a produção imobiliária com a renda da terra, além de ser determinado pelos custos com terreno, força de trabalho e materiais de construção, também se origina de uma renda imobiliária cobrada pela indústria da construção. Esta baseada, dentre outros aspectos, na localização e pela capacidade da produção imobiliária se apropriar do ambiente construído.

Quem que vai determinar o limite dos preços dos produtos imobiliários será o promotor imobiliário a partir de análises do processo da construção e do próprio mercado, podendo, a partir disso, estabelecer um preço de venda superior (ou muito superior como no caso do Vila Imperial) ao preço dos custos totais da construção (considerando o custo da construção acrescido o valor do terreno). Esse preço conforme Tone (2010), é definido essencialmente, pelas possibilidades de pagamento na disputa pela apropriação do espaço.

Mas os empreendimentos em geral buscam aumentar e justificar seus preços utilizando outras diversas estratégias como, por exemplo, o marketing imobiliário que busca tornar cada empreendimento singular. Neste sentido, destaca-se um discurso e uma apropriação mercadológica no que diz respeito ao lazer, qualidade de vida, proximidade com a natureza e segurança. Essa apropriação da natureza e da qualidade de vida com lazer e segurança que esses empreendimentos oferecem contribui tanto para apresentar esses empreendimentos como singulares, como também para que eles estabeleçam preços mais elevados. Nesta direção, pode-se dizer que a lógica da construção é buscar evidenciar as desigualdades espaciais de maneira que cada lugar se pareça único para a partir de então, justificar seu preço (CAMPOS JR, 2002). Além disso, outro fator que pode, de certo modo, interferir no preço dos imóveis pode ser compreendido pelo fato do mesmo também apresentar uma possibilidade de renda a seu proprietário caso este alugasse o imóvel. Ou seja, o proprietário do imóvel poderia obter uma renda (na forma de aluguel) pelo fato do controle privado de um espaço, no caso, o espaço de moradia.

De maneira geral, a definição do preço do produto imobiliário bem como sua possibilidade de valorização extrapola o processo de construção em si, em função das características que a terra e o produto imobiliário integrado a ela representam e pelas estratégias utilizadas para justificar, em parte, os preços dos imóveis. Segundo Tone (2010) este processo característico da produção imobiliária promove um relativo desinteresse no aumento da produtividade do trabalho na construção, mantendo-a como produção manufatureira. Em paralelo, essa produção imobiliária motiva a elevação nos preços dos imóveis e terrenos ao longo do tempo, implicando em uma organização desigual da cidade.

Em síntese, enquanto os promotores imobiliários e até mesmo os proprietários fundiários lucram com o PMCMV - como evidenciou o caso do Vila Imperial que foi o empreendimento que apresentou a mais alta taxa de lucro, a mais alta taxa de mais 
valia e a mais alta taxa de renda da terra - e outros produtos imobiliários, ocorre uma mercantilização generalizada do espaço urbano, tornando o mesmo cada vez mais fragmentado e segregado. Deste modo, nota-se que o espaço urbano vem se colocando em uma condição que permite a realização de valorização de capitais por meio da mercantilização de terras, da exploração do trabalho e da produção de novos produtos imobiliários. Em suma, para os promotores imobiliários e para o capital em geral, fabricar cidade se tornou um negócio muito rentável.

\section{Considerações finais}

O trabalhou procurou demonstrar como que os promotores imobiliários em busca da valorização de seus capitais via produção imobiliária se relaciona com a propriedade da terra, e os fatores de produção (capital constante e variável) no processo de construção. Neste sentido percebemos que a renda da terra, equivalente ao preço da terra, que em um primeiro momento pode se apresentar como barreira para a produção imobiliária, acaba sendo apropriada pelas lógicas imobiliárias onde o promotor imobiliário inclui o preço da terra no custo da construção e ao mesmo tempo se apropria do espaço construído e da localização para estabelecer preços de monopólio sobre eles. Como consequência disso, o promotor imobiliário que havia pagado a renda da terra na aquisição da terra, consegue se apropriar da renda da terra após a construção do empreendimento, uma vez que ele detém o monopólio sobre uma fração de terra. Essa apropriação da renda da terra fica bem claro quando analisamos as taxas de renda da terra, essa que nos 13 empreendimentos analisados apresentou uma média de 7,96. Ou seja, quase 8 vezes maior é a relação da mais valia (lucro) com o preço da terra. Quanto ao trabalho, notou-se que na produção imobiliária se encontra uma grande exploração de trabalho. Fato evidenciado pela taxa de mais valia que representa o trabalho não pago aos trabalhadores, em média entre os 13 empreendimentos tivemos uma taxa de exploração de aproximadamente 4,91. Ou seja, o valor da mais valia é 4,91 vezes maior do que o valor pago aos trabalhadores. Esses ganhos imobiliários advindo da exploração do trabalho nos ajuda a compreender o relativo desinteresse no aumento da produtividade do trabalho na construção via emprego de novas tecnologias, mantendo-a como produção manufatureira.

As análises das taxas de mais valia e de renda da terra além de ajudar a compreender algumas relações entre a produção imobiliária, a propriedade da terra e o trabalho, também nos ajuda a compreender como se origina os lucros dos promotores imobiliários e ao mesmo tempo compreender porque a produção imobiliária de mercado se apresenta como um setor capaz de absorver e revalorizar capitais.

\section{Referências Bibliográficas}

CAMPOS JR., C. T. A construção da cidade: formas de produção imobiliária em Vitória. Vitória: Flor\&cultura, 2002. 
FERREIRA, F. C. A produção imobiliária e a renda da terra: estudos de alguns casos na Região Metropolitana da Grande Vitória (RMGV). Monografia Departamento de Geografia - UFES, 2014.

FERREIRA, F. C. Propriedade fundiária, os "vazios urbanos" e a organização do espaço urbano: o caso de Serra na Região Metropolitana da Grande Vitória - ES (RMGV-ES). Dissertação Mestrado. Mestrado em Geografia - UFES, 2015.

GONÇALVES, Thalismar Matias. Novas estratégias da produção imobiliária na Grande Vitoria: um estudo sobre as recentes transformações do espaço urbano de Serra-es. Dissertação Mestrado. Mestrado em Geografia-UFES, 2010.

HARVEY, David. A Justiça Social e a Cidade. São Paulo: Hucitec, 1980.

HARVEY, David. Os limites do Capital. São Paulo. Boitempo. 2013.

HARVEY, David. Cidades Rebeldes. Do direito a cidade a revolução urbana. Martins Fontes, São Paulo, 2014.

INSTITUTO BRASILEIRO DE GEOGRAFIA E ESTATÍSTICA (IBGE). Censo populacional de 2010. Rio de Janeiro, 2010.

LEFEBVRE, H. A produção do espaço. Trad. Doralice Barros Pereira e Sérgio Martins (do original: La production de l'espace. 4e éd. Paris: Éditions Anthropos, 2000).

LEFÈVRE, Rodrigo Brotero. Notas sobre o papel dos preços de terrenos em negócios imobiliários de apartamentos e escritórios, na cidade de São Paulo. In MARICATO, Ermínia (org). A Produção Capitalista da Casa (e da Cidade) no Brasil Industrial. São Paulo: Alfa-Ômega, 1979, pp. 21 -71.

LIPIETZ, Alain. Una versión marxista de la renta del suelo urbano. in. PARDO M. M. Estudios sobre la renta del suelo. Communidad Madrid, 1985.

MARX, Karl. O Capital: O processo global da produção capitalista. Tomo 2 (Parte Segunda). Tradução Regis Barbosa e Flávio R. Kothe. São Paulo: Nova Cultura, 1988. Vol. V. Livro Terceiro.

PEREIRA, Paulo Cesar Xavier. Espaço, técnica e construção: o desenvolvimento das técnicas construtivas e a urbanização do morar em São Paulo. São Paulo: Nobel, 1988.

RONCHI, Pedro. Expansão urbana e o Programa Minha Casa, Minha Vida na Região Metropolitana da Grande Vitória. Dissertação Mestrado. Mestrado em Geografia - UFES, 2014.

SINDUSCON-ES. Considerações Metodológicas sobre o CUB disponível em: http://www.sinduscon-es.com.br/sinduscon/index.htm acessado em 04/02/2014.

TONE, Beatriz Bezerra. Notas sobre a valorização imobiliária em São Paulo na era do capital fictício. Dissertação de Mestrado da FAUUSP. São Paulo, 2010. 
ZANOTELLI C. L., et. al. A renda da terra na Região Metropolitana da Grande Vitória - ES - Brasil, Confins, 21 | 2014, mis en ligne le 20 juin 2014, consulté le 12 janvier 2015. URL: http://confins.revues.org/9738; DOI: 10.4000/confins. 9738.

\section{Francismar Cunha Ferreira}

Possui Mestrado em Geografia pela Universidade Federal do Espírito Santo, onde também cursou licenciatura plena e bacharelado em Geografia.

Rua Jardim América, 22, Bela Aurora. CEP 29.141.514 - Cariacica-ES.

E-mail: Francismar.cunha@gmail.com

\section{Cláudio Luiz Zanotelli}

Possui Licence em Planejamento Regional pela Université de Paris X, Nanterre, França, Maîtrise em Planejamento e Urbanismo e Doutorado em Geografia Humana, Econômica e Regional pela Université de Paris X, Nanterre. Atualmente é professor Titular da Universidade Federal do Espírito SantoUFES.

Av. Fernando Ferrari, S/N Goiabeiras. CEP, 29.060.900 - Vitória-ES.

E-mail: clzanotelli@yahoo.com.br

Recebido para publicação em novembro de 2015. Aprovado para publicação em março de 2016. 